\title{
MICROBIAL COMMUNITY OF BLACK BAND DISEASE ON INFECTION, HEALTHY, AND DEAD PART OF SCLERACTINIAN Montipora sp. COLONY AT SERIBU ISLANDS, INDONESIA
}

\author{
Ofri Johan"*\#, Dietriech G. Bengen ${ }^{* * *}$, Neviaty P. Zamani**), Suharsono ${ }^{* * * *}$,

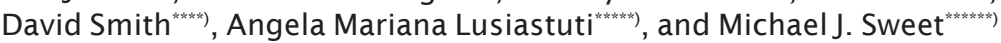 \\ ") Research and Development Institute for Ornamental Fish Culture, Jakarta \\ ${ }^{*}$ Department of Marine Science and Technology, Faculty of Fisheries and Marine Science, \\ Bogor Agricultural University \\ **a) Research Center for Oceanography, The Indonesian Institute of Science \\ ****) School of Biology, Newcastle University, NE1 7RU, United Kingdom \\ *enter for Aquaculture Research and Development \\ Biological Sciences Research Group, University of Derby, Kedleston Road, Derby, DE22 1GB, \\ United Kingdom
}

(Received 19 March 2014; Final revised 12 September 2014; Accepted 10 November 2014)

\begin{abstract}
It is crucial to understand the microbial community associated with the host when attempting to discern the pathogen responsible for disease outbreaks in scleractinian corals. This study determines changes in the bacterial community associated with Montipora sp. in response to black band disease in Indonesian waters. Healthy, diseased, and dead Montipora sp. ( $\mathrm{n}=3$ for each sample type per location) were collected from three different locations (Pari Island, Pramuka Island, and Peteloran Island). DGGE (Denaturing Gradient Gel Electrophoresis) was carried out to identify the bacterial community associated with each sample type and histological analysis was conducted to identify pathogens associated with specific tissues. Various Desulfovibrio species were found as novelty to be associated with infection samples, including Desulfovibrio desulfuricans, Desulfovibrio magneticus, and Desulfovibrio gigas, Bacillus benzoevorans, Bacillus farraginis in genus which previously associated with pathogenicity in corals. Various bacterial species associated with uninfected corals were lost in diseased and dead samples. Unlike healthy samples, coral tissues such as the epidermis, endodermis, zooxanthellae were not present on dead samples under histological observation. Liberated zooxanthellae and cyanobacteria were found in black band diseased Montipora sp. samples.
\end{abstract}

KEYWORDS: bacteria, black band disease, Montipora sp., Seribu Islands

\section{INTRODUCTION}

Vast research throughout the Caribbean over the past few decades has provided great insight into the epidemiology of coral disease, providing a platform that can be utilised in other regions of the world. In the mid 1990s, 18 types of coral disease were recorded, infecting at least 150 species of scleractinian, gorgonian,

\# Corresponding author. Research and Development Institute for Ornamental Fish Culture Jl. Perikanan No. 13, Pancoran Mas, Depok 16436, Indonesia. Phone: +62 217520482

E-mail: ofrijohan@kkp.go.id 
and hydrozoans corals throughout the Caribbean and Indo-Pacific. Despite this, Koch's postulates (to determine the causal agent of a disease) have only been fulfilled for 5 of these 18 diseases (Sutherland et al., 2004).

Bacterial infections of corals can lead to devastating large-scale losses on coral reefs, resulting in reef deterioration and a disturbance for the ecosystem as a whole (Harvell et al., 2007).

Black Band Disease (BBD) is a classic example of such an infection, where by the disease can reduce and alter the structure of coral reef communities (Rosenberg \& Loya, 2004). The extent of damage from BBD in Indonesian reefs has yet to be reported.

Changes in the bacterial communities associated with corals have been identified in various infectious diseases of corals and can be used to determine the causal agent of a given disease, including that of Black Band Disease. BBD can be found in various coral species (Voss, 2006), including, the massive corals (Frias-Lopez et al., 2004), Faviidae (Barneah et al., 2007) and coral foliose (Sato et al., 2010). The disease has also been found to have a wide geographic distribution, having been identified in the Caribbean, Indo-Pacific waters, the Red Sea, the Great Barrier Reef (Willis et al., 2004), as well as Indonesian waters (Haapkylä et al., 2007).

Previous research has proposed that the primary cause of Black Band Disease is the bacteria Phormidium corallyticum, but further clarification is necessary to support this claim (Cooney et al., 2002). It has also been suggested that BBD is caused by a consortium of microorganisms which are being dominated by cyanobacteria. Cyanobacteria are made up of an array of species, including filamental Phormidium corallyticum, heterotrophic bacteria (Garrett \& Ducklow, 1975), marine fungi (Ramos-Flores, 1983) and bacteria that can oxidizes sulfite (Beggiatoa) and sulphate reducing (Desulfovibrio) (Ducklow \& Mitchell, 1979; Richardson, 1996).

Black Band Disease is characterized by the presence of a progressive black band (width 5-30 $\mathrm{mm}$ ) on the surface of a coral, leaving a bare skeleton with a lack of soft tissue behind. The rate at which these bands progress can reach up to $2 \mathrm{~cm}$ per day (Rutzler et al., 1983), with exposed skeleton being quickly colonised by algae. As BBD appears to be activated at temperatures exceeding $28^{\circ} \mathrm{C}$, infections are found to increase during summer months and dramatically decrease in winter (Cooney et al., 2002), suggesting the causal agent may be a thermophilic organism.

The use of molecular techniques to determine bacterial causal agents of coral diseases, (including BBD) has yet to be conducted for disease cases from Indonesia. Several studies have reported the different in bacterial communities found on corals with different surrounding environment such as aquaria and nature (Sweet et al., 2011 ; Sweet et al., 2012). This valuable approach can be used to analyse microbial community structure and species composition associated with diseased tissues, through the amplification of ribosomal DNA (rDNA) using specific 15S rRNA primers, via polymerase chain reaction (PCR), followed by sequence analysis of cloned rDNA (Muyzer et al., 1993).

This study aims to identify the prevalence of BBD across three different Indonesian reefs, all at different distances from the mainland of Java Island. Additionally, the prokaryotic community associated with healthy, BBD diseased and dead tissue is also determined, helping to elucidate the causal agent of this disease at these locations.

\section{MATERIALS AND METHODS}

\section{Sample Collection}

Coral samples were taken from zone 1 (Pari Island), zone 2 (Pramuka Island) and zone 3 (Penjaliran Island) using hammer and punch. Three different types of sample were collected, based on disease state, including healthy tissue, BBD-affected tissue and dead tissue from the same coral colony. Samples were taken and measured $5 \mathrm{~cm}^{2}$ in 4 replicates of each sample. Samples were collected for the purposes of identifying associated bacteria and histology (Figure 1).

Upon collection, samples for prokaryotic analysis were placed into separate sterile containers containing 70\% ethanol, allowing samples to be preserved until DNA extraction could take place at the Coral Health and Disease laboratory at the Newcastle University School of Biology, United Kingdom.

Samples for histological analysis were suspended in seawater taken from the reef upon 


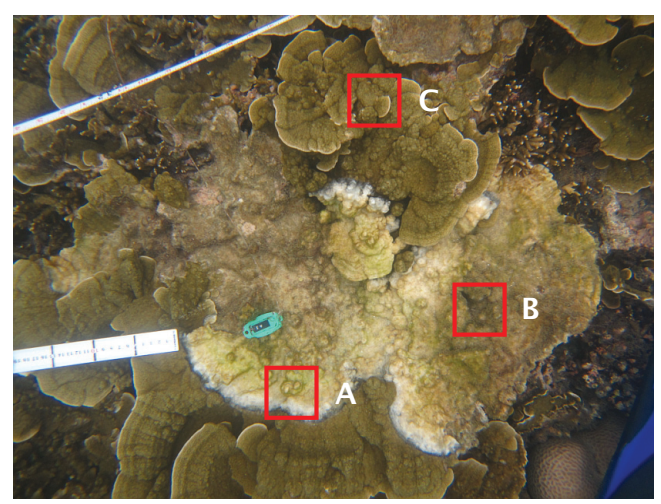

Figure 1. Photograph representing the manner in which samples were collected for the determination of bacterial communities associated with tissue type and histological analysis. Black band diseased sample (A), dead sample (B), and healthy sample (C)

collection before further sample preparation was conducted at Newcastle University.

\section{Bacteria Identification}

Coral samples were crushed with a sterile pestle and mortar and DNA was subsequently extracted using a Blood and Tissue DNA Extraction Kit (Qiagen). PCR was carried out, following the same protocol as Smith et al. (2014) using a Hybaid thermal cycler to amplify target 16S rRNA using the primers 357f-GC-518r (Muyzer et al., 1993). Denaturing Gradient Gel Electrophoresis (DGGE) was utilised to profile the bacterial community based on the separation of 16S rRNA bands, which were subsequently purified using a Qiagen Gel Extraction Kit. DGGE was conducted according to Smith et al. (2014). Purified samples were sent for sequencing at Genevision (Newcastle University). Sequence data was analysed by comparing sequences with those in the BLAST database (http://blast.ncbi.nlm.nih.gov/) to identify the species of bacteria (Altschul et al., 1997).

\section{Histology}

Healthy, BBD-affected, and dead coral samples were preserved in $5 \%$ paraformaldehyde (diluted with seawater) for a minimum period of one week, then decalcified using 10\% EDTA (dissolved in distilled water) over a pe- riod of weeks, with the 10\% EDTA being replaced for a fresh $10 \%$ EDTA in every few days. The healthy, BBD-affected and dead Montipora sp. samples for histological analysis were prepared and sectioned following the same protocol used by Smith et al. (2014).

\section{Data Analysis}

Similarities in the microbial community associated with the different sample types (healthy, BBD-affected, and dead) were analyzed using BioNumeric software. This analysis identified 18 bands across all sample types, each band representative of a dominant prokaryotic member of the microbial community.

\section{RESULTS \\ Bacteria Associated with Coral Samples}

Based on DGGE analysis of the dominant prokaryotic community, 18 different bacterial species were identified across all three sample types (Figure 2). The diversity of bacteria in BBD-affected corals was higher than in healthy and dead corals samples.

\section{Healthy Coral Samples}

Species identified across all healthy samples include those represented by the following bands; 1 (Halomonas anticariensis), 8 (Pseudoalteromonas denitrificans), 13 (Psychromonas ingrahamii), 16 (Shewanella benthica), 17 (Shewanella loihica), and band 18 (Vibrio fischeri). Band 13 (Psychromonas ingrahamii) was only found in two healthy samples $(\mathrm{H} 1$ and H2) (Figure 2).

Bacteria of the Halomonas genus are halophilic bacteria, usually isolated from highly saline environments. They are gram-negative bacteria that live at temperatures range of $20^{\circ} \mathrm{C}-45^{\circ} \mathrm{C}$ and at $\mathrm{pH}$ 6-9 (Martinez-Canovas et al., 2004). Halomonas anticariensis (Gammaproteobacteria) was first isolated from highly saline found in peatland environments. Bacterium belonging to the genus Halomonas have been found on the coral species Acropora sp. tissue. Pseudoalteromonas denitrificans, belongs to genus of bacteria often associated with a host organism from the marine environment, such as fish, mollusks, tunicates, sponges, and micro and macro algae. Some members of the genus Pseudoalteromonas (including $P$. denitrificans) have been found pro- 


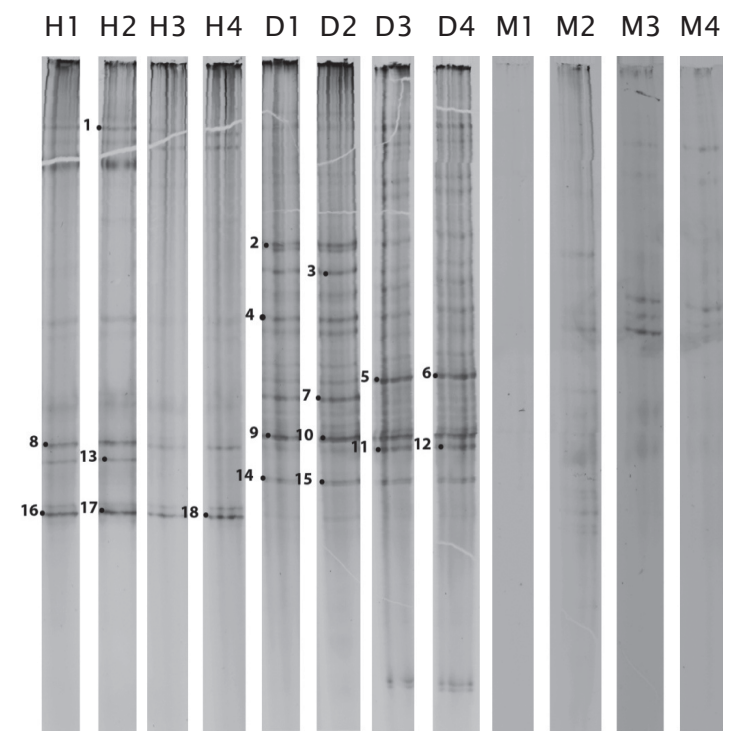

Note:

1. Halomonas anticariensis

2. Burkholderia bryophila

3. Flavobacterium columnare

4. Sulfurihydrogenibium sp.

5. Desulfovibrio desulfuricans

6. Sporobacterium olearium

7. Bacillus farraginis

8. Pseudoalteromonas denitrificans

9. Desulfovibrio gigas

10. Bacillus benzoevorans

11. Desulfovibrio magneticus

12. Pseudoalteromonas peptidolytica

13. Psychromonas ingrahamii

14. Sphingomonas wittichii

15. Thiobacillus denitrificans

16. Shewanella benthica

17. Shewanella loihica

18. Vibrio fischeri

Figure 2. Band profile of DGGE result on DNA extraction of health $(\mathrm{H} 1-\mathrm{H} 4)$, disease (D1-D4) and dead sample (M1-M4) by gen test using primer 16S rRNA and PCR application

ducing active compounds which also being isolated from seawater samples (Skovhus et al., 2004). Pseudoalteromonas ruthenica has previously been isolated from the coral Acropora sp. (Raina et al., 2009).

Vibrio fischeri (of the family Vibrionaceae) is a motile, gram-negative, rod-shaped bacteria found in both seawater and freshwater. Vibrio fischeri are also bioluminescent and are often found in symbiosis with marine animals such as squid (Small \& McFall-Ngai, 1999). Vibrio fischeri has previously been identified in the coral Acropora sp. (Raina et al., 2009). Vibrio spp. are often associated with coral pathogenicity, thus it is interesting to see how they are associated with healthy coral samples in this instance.

Shewanella spp. are gram-negative bacteria and have previously been identified across a range of environments, including marine environments, freshwater rivers and lakes, and soil. This genus has previously been discovered by other researchers on healthy corals such as Shewanella sp. (Sekar et al., 2006), Bacillus algicola (Sabdono \& Radjasa, 2006), Halomonas sp. (Ojima et al., 2012), and Sphingomonas wittichii (Rosenber \& Ben-Haim, 2002).

There are 9 genera bacteria associating with the coral i.e. Vibrio sp., Alteromonas sp.,
Psychrobacter sp., Ralstonia sp., Silicibacter sp., Bacillus sp., and Cytophaga sp. (Abdelnasser \& Ibrahim, 2008).

\section{Black Band Disease Samples}

Bacterial bands associated with BBD-affected coral samples (Figure 2) i.e., Burkholderia bryophila (2), Flavobacterium columnare, (3) Sulfurihydrogenibium sp. (4), Desulfovibrio desulfuricans (5), Sporobacterium olearium (6), Bacillus farraginis (7), Desulfovibrio gigas (9), Bacillus benzoevorans (10), Desulfovibrio magneticus (11), Pseudoalteromonas peptidoIytica (12), Sphingomonas wittichii (14), and Thiobacillus denitrificans (15).

Almost all of the bands associated with BBD samples were found across all BBD samples, including bands 2-6, and 9-15. Band 7 was only found in two BBD-affected samples (D1 and D2) (Figure 2).

Desulfovibrio spp. are gram-negative bacteria, generally associated with marine, brackish and freshwater environments. Their presence is also found to flourish as the environment becomes more anoxic. Desulfovibrio spp. belong to a class of bacteria that reduce sulfate and thus they have a role in the cycling of sulfur. In corals, this would cause localised anoxia and increased sulphide levels in host tissues, which would be harmful to the coral 
and could ultimately result in colony death (Viehman et al., 2006). Further, Viehman et al. (2006) state that many previous molecularbased studies have found several Desulfovibrio spp. to be associated with black band disease.

Bacillus spp. are ubiquitous in nature and this genus is found to include free-living and pathogenic species. Bacillus spp. are grampositive, rod-shaped bacteria that can be grown in aerobic and anaerobic conditions. Spores from Bacillus spp. are resistant to heat (high temperature). These bacteria are known to degrade xylan and carbohydrates, as well as catalyse enzymes. Bacillus spp. have previously been isolated from the sponge species Petromica citrina and Chelonaplysilla erecta (Bastos et al., 2013).

The genus Burkholderia belongs to the betaproteobacteria group, comprising more than 60 species which can be found in several habitats such as, water, plant roots, or it can be a causal disease in plants or humans (Santos et al., 2013). Despite this, this is the first report of bacteria belonging to this genus in coral reefs and diseased corals.

Flavobacterium columnare is a gram-negative, rod-shaped bacteria which has previously been found to cause disease in freshwater fish. This species can produce an enzyme that degrades chondroitin sulfate (Figueiredo et al., 2005). This is the first report of this species in a diseased coral.

Sulfurihydrogenibium spp. are motile, gramnegative, rod-shaped bacteria capable of oxidizing sulphur, such that they are believed to play an important role in the sulfur cycle (Nakagawa et al., 2005). These bacteria have previously been associated with pathogenicity in corals.

Sporobacterium olearium bacteria can damage methoxylated aromatic compounds and syringate in significant amounts in the presence of sulfide. These bacteria can be found in both freshwater sediments and the marine environment (Lomans et al., 2001), although there are no previous reports associating it with corals and pathogenicity in corals.

Pseudoalteromonas peptidolytica are motile, gram-negative bacteria belonging to the class Gammaproteobacteria. This bacteria is associated with aerobic environments and has previously been isolated from seawater in the Sea of Japan. Interestingly, bacteria of this ge- nus have previously been reported as pathogens in fish (Vynne, 2011) and mussels (Venkateswaran \& Dohmoto, 2000).

Pseudoalteromonas ruthenica has previously been isolated from the coral Acropora sp (Raina et al., 2009).

Sphingomonas wittichii is an alphaproteo bacteria and was first isolated from river water. It is known to be a good metabolizer of dibenzop-dioxin (Yabuuchi et al., 2001). Sphingomonas spp. are gram-negative, rod-shaped, chemoheterotrophic bacteria usually associated with an oxygenated environment. These bacteria can cause disease in humans (especially Sphingomonas paucimobilis). Sphingomonas bacteria are ubiquitous in nature, have been isolated from soil, water and plant roots, largely these bacteria are able to survive in low nutrient conditions. To date, these bacteria have not been associated with pathogenicity of corals.

Thiobacillus denitrificans are gram-negative, rod-shaped bacteria, belonging to the class betaproteobacteria. These bacteria have been found in seawater sediments and are able to oxidize sulfur to sulfate, a process in line with the absorption of oxygen and nitrate reduction (Aminuddin, 1979). Thiobacillus denitrificans is also able to reduce nitrate and nitrite (Haaijer et al., 2006). This bacterium has not been reported to infect corals.

Out of the bacteria found in BBD-affected samples, many of them belong to the group Cyanobacteria, such as Desulfovibrio desulfuricans, Desulfovibrio gigas, Desulfovibrio magneticus, Bacillus farraginis, Bacillus benzoevorans. Cyanobacteria are a major cause of black band disease in corals (Richardson, 1998).

\section{Dead Coral Samples}

Few bands were found on dead coral samples and of those bands identified, none were found consistently across all dead samples (M1-M4).

It is evident that Black Band disease begins with high abundance of cyanobacteria, known as cyanobacterial patches (CP). CPs were found on several colonies of Montipora spp. in shallow waters at Pramuka Island which were overgrown with algae a few days later, indicating those coral colonies had died. Tissue damage between $\mathrm{CP}$ and BBD can be eas- 
ily distinguished in the field, as CPs are not associated with a black belt. Colonies found to have a CP did not always develop BBD (Figure 3). These observations are similar to that reported by Sato et al. (2010) in the Great Barrier Reef.

CPs identified in Montipora sp. colonies (Figure 3A) were found to grow in size after 2 weeks (Figure 3B). Exposed skeleton was then subsequently colonised by algae (Figure $3 C$ ). Microscopic observations of CPs revealed a large numbers of cyanobacteria filaments.

\section{Histology Observation}

It was easy to indicate epidermis layer, gastrodermis, as well as zooxanthellae in healthy Montipora sp. samples, whereas these tissue structures were found to be broken down in BBD samples. Long, rod-shaped structures resembling filamental cyanobacteria were identified in abundance in BBD samples (Figure 4B). These cyanobacteria were not found in dead coral samples and zooxanthellae were also can not be found along with any healthy tissue structure.
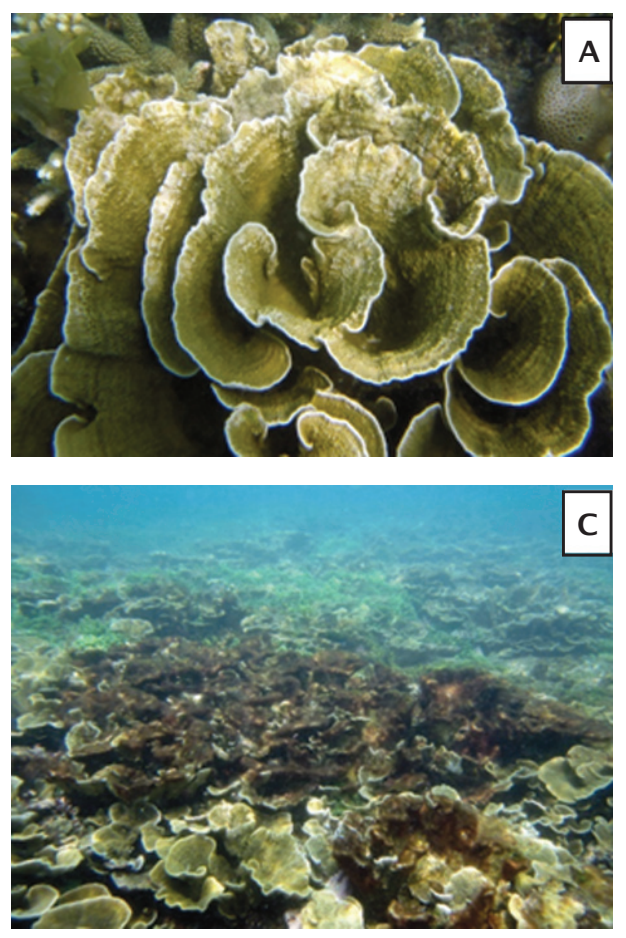

Bacterial communities were grouped and undergo a treatment in accordance with the samples between healthy $(H)$ and diseased (D) coral. Excluding the samples of dead coral that $2 \mathrm{M} 2$ is not clustered either to $3 \mathrm{M} 1$ and $2 \mathrm{M} 2$ samples. The test results explained that the bacteria live on the healthy coral is different with diseased and dead sample (Figure 5).

\section{DISCUSSION}

There are 3 species of Desulfovibrio spp. found on infected coral samples in the Seribu Islands i.e. Desulfovibrio magneticus, Desulfovibrio gigas, and Desulfovibrio desulfuricans. Desulfovibrio spp. are pathogenic because they produce and accumulate sulfide in high concentrations in black band disease, giving rise to anoxic conditions, which ultimately leads to coral mortality (Richardson et al., 1997).

Another type of bacteria found in BBD infected samples at Seribu Islands were Bacillus spp. (Bacillus benzoevorans and Bacillus farraginis). Although these species have not been reported to be pathogenic to corals in the past, Bacillus spp. have been found to have
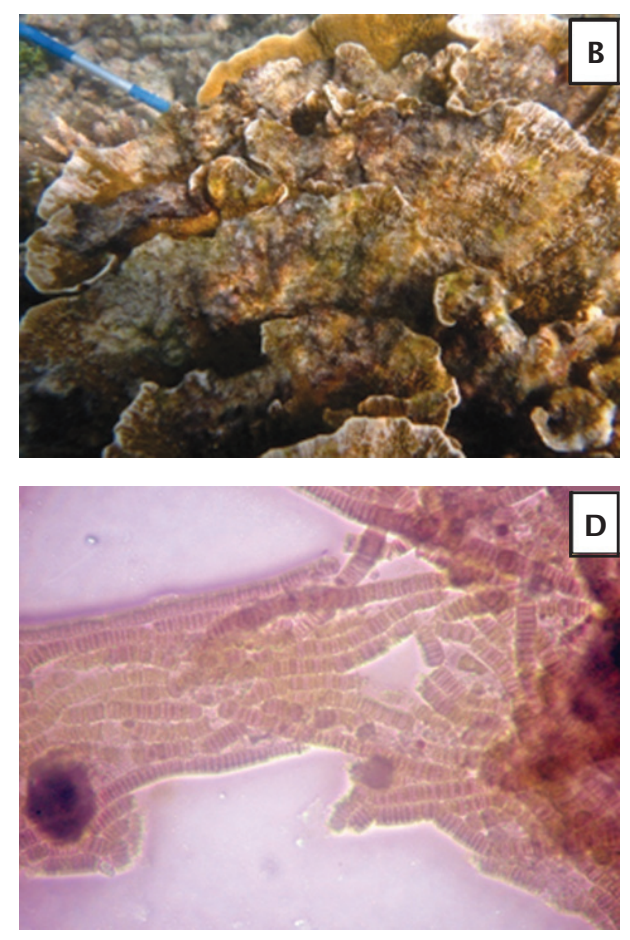

Figure 3. Montipora sp. with CP (A, B) after overgrown with algae (C) and cyanobacteria patches (CP) under microscope observation $40 x$ cyanobacterial filaments (D) 

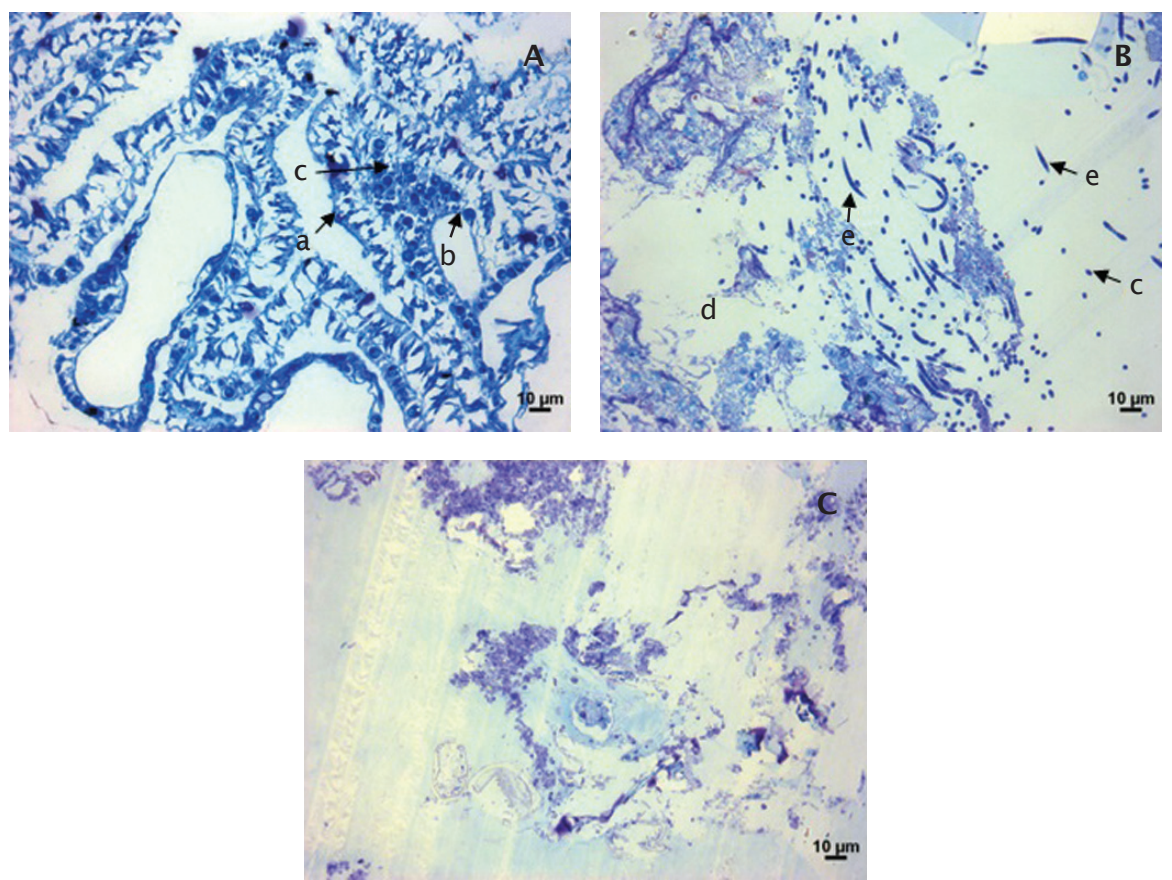

Figure 4. Histological sections of healthy (A), Black Band Disease (B), and dead (C) Montipora sp. tissue under light microscopy (magnification $\times 40$ ), stained with toluidine blue. Specific coral tissues are labelled, including epidermis (a), endodermis (b), and zooxanthellae (c). Infected coral samples (B); damaged coral tissue (d) and cyanobacteria (e)

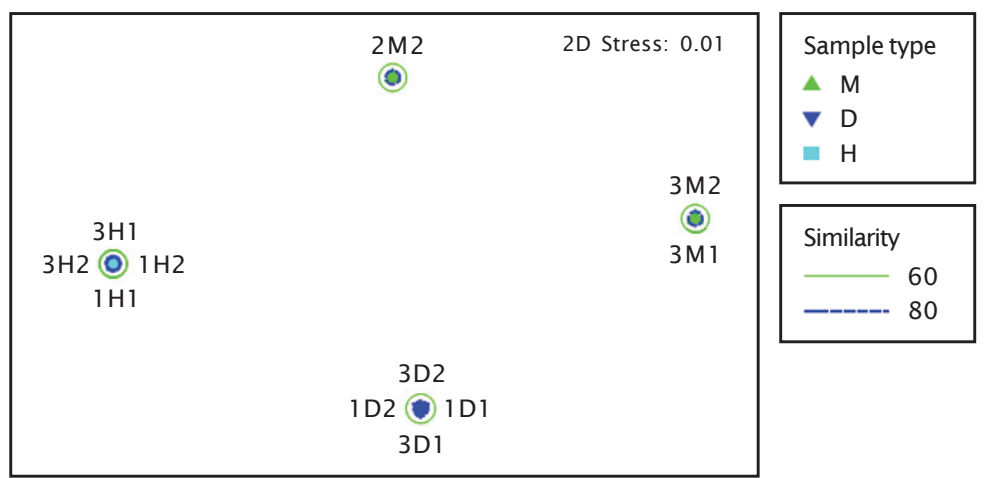

Figure 5. The similarity rate of bacteria on healthy, infected, and dead sample according to different sites by using Primer 6 programme

antibacterial properties against other bacteria and their influx could disrupt the native coral microbiota (Sabdono \& Radjasa, 2006). This could potentially having a negative impact upon symbioses between the host coral and microbial members of the holobiont if key species are reduced/lost.
Sulfurihydrogenibium sp. is a bacteria that canoxidize hydrogen and sulfur (Hirayama et al., 2005), but there is no report that describes it as a pathogenic bacteria in corals.

Shewanella sp. was found to be associated with healthy Montipora sp. samples in the 
present study, coinciding with previous reports that associate this bacteria with healthy corals (Frias-Lopez et al., 2002). Despite this, other studies have also found these bacteria to be associated with infected corals (Sekar et al., 2006), thus there is the potential that healthy samples harbouring this bacterial species may become diseased following an influx associated with favourable environmental conditions (Frias-Lopez et al., 2002; and Rohwer et al., 2002).

Sphingomonas sp., found in BBD samples in the present study, have previously been associated with healthy coral (Rosenberg \& Ben-Haim, 2002). That said, members of this genus have also been associated with corals suffering from White Plague in Florida, demonstrating their pathogenic potential (Ravindran et al., 1998).

Although Black Band Disease (BBD) has been known for decades (since 1970), the main pathogenic bacteria of the disease has yet to be identified. Previously, it was considered that BBD was caused by the bacteria Phormidium corallyticum. But, the use of molecular techniques to identify the microbial community associated with this disease has led to the discovery of a consortium of bacteria associated with BBD (Frias-Lopez et al., 2004). This consortium is comprised of various cyanobacteria, sulfate-reducing bacteria such as Desulfovibrio spp., sulfide-oxidazing Beggiatoa spp. and marine fungi. This makes it difficult to fulfil Koch's postulates for BBD, as this approach is more suited to diseases with single or minimal causal agents (Richardson, 1998; Sutherland et al., 2004).

Sato et al. (2010) has identified 262 cases of CP in Montipora sp. in the Great Barrier Reef and $18.7 \%$ of these cases developing into BBD. In contrast to this, CP cases in Montipora spp. in the Thousand Islands ( or Seribu Island) were not found to develop into BBD, with a recent outbreak of BBD reaching a recent peak (Johan, 2013, pers obs) appearing to exist as a separate disease.

\section{CONCLUSION}

Bacteria belonging to the genus Bacillus sp., Sulfurihydrogenibium sp. and Desulfovibrio spp. are associated with BBD in Montiporasp. in Indonesian reefs, with Desulfovibrio spp. appearing to be a strong causal agent for this disease. Sphingomonas wittichii, Halomonas sp., Bacillus algicola, and Shewanella sp. are all associated with the healthy Montipora sp. holobiont in this region. Following histological analysis, there are marked differences between healthy, BBD-affected and dead Montipora sp. tissues. In BBD-affected samples, there is mass breakdown in host tissue, zooxanthellae are lost and filament-shaped bacteria are present. These filament-shaped bacteria are lost in dead samples, thus clearly demonstrating their presence is strongly associated with BBD tissues.

\section{ACKNOWLEDGEMENTS}

The authors would like to thank the Ministry of Marine Affairs and Fisheries for providing study fees and the fellowship from The World Bank, tied with the Robert S. McNamara Fellowships Program (RSM), Coral Health and Disease Laboratory, Newcastle University (UK) in assisting in analyzing bacteria associated with coral samples. This research was also supported by funding from the Center for Aquaculture Research and Development, and Bogor Agriculture University. The authors would also like to thank those who helped with data collection, Jhon Bythell who help in process to get funding in this analysis as well as the Seribu Islands National Park, Jakarta, for allowing use as a research location.

\section{REFERENCES}

Abdelnasser, S., \& Ibrabim, S. (2008). Diversity of coral Euniceafusca associated bacteria using culture dependent techniques. Research Journal of Microbiology, 3(10), 614621.

Altschul, S.F., Madden, T.L., Schaffer, A.A., Zhang, J., Zhang, Z., \& Miller, W. (1997). Gapped BLAST and PSI-BLAST: a new generation of protein database search programs. Nucleic Acids Res., 25: 3389-3402.

Aminuddin, M. (1979). The oxidation of elemental sulphur by Thiobacillus denitrificans. Pertanika, 2(1), 21-27.

Barneah, O., Eitan Ben-Dov, Kramarsky-Winter, E., \& Kushmaro, A. (2007). Characterization of black band disease in Red Sea stony corals. Environmental Microbiology, 9(8), 1995-2006.

Cooney, R.P., Pantos, O., Le Tissier, M.D.A., Barer, M.R., O'Donnell, A.G., \& Bythell JC. (2002). Characterization of the bacterial consortium associated with black band dis- 
ease in coral using molecular microbiological techniques. Environmental microbiology, 4(7), 401-13. Retrieved from http:// www.ncbi.nIm.nih.gov/pubmed/ 12123476.

Ducklow, H.W., \& Mitchell, R. (1979). Composition of mucus released by coral reef coelenterates. Limnol. Oceanogr., 24(4), 706714.

Fadlallah, Y.H., \& Pearse, J.S. (1982). Sexual reproduction in solitary corals: synchronous gametogenesis and broadcast spawning in Paracyathus stearnsii. Mar. Biol., 71, 233239.

Figueiredo, H.C.P., Klesius, P.H., Arias, C.R., Evans, J., Shoemaker, C.A., Pereira, Jr. D.J., \& Peixoto, M.T.D. (2005). Isolation and characterization of strains of Flavobacterium columnare from Brazil. Journal of Fish Diseases, 28, 199-204.

Frias-lopez, J., Bonheyo, G.T., \& Fouke, B.W. (2004). Identification of differential gene expression in bacteria associated with coral black band disease by using RNA-Arbitrarily primed PCR, 70(6), 3687-3694. doi:10.1128/AEM.70.6.3687.

Frias-Lopez, J., Zerkle, A.L., Bonheyo, G.T., \& Fouke, B.W. (2002). Partitioning of bacterial communities between sea-water and healthy, black band diseased, and dead coral surfaces. Appl. Environ. Microbiol., 68, 2214-2228.

Garrett, P., \& Ducklow, H. (1975). Coral disease in Bermuda. Nature, 253, 349-350. doi:10. 1038/253349a0.

Glynn, P.W., \& De Weerdt, W.H. (1991). Elimination of two reef building hydrocorals following the 1982-83 El Niño warming event. Science, 253, 69-71.

Glynn, P.W. (1994). State of coral reefs in the Galapagos Islands: natural vs anthropogenic impacts. Marine Pollution Bulletin, 29, 131-140.

Haaijer, S.C., Van der Welle, M.E., Schmid, M.C., Lamers, L.P., Jetten, M.S., \& Op den Camp, H.J. (2006). Evidence for the involvement of betaproteobacterial Thiobacilli in the nitrate-dependent oxidation of iron sulfide minerals. FEMS Microbiology Ecology, 58, 439-448.

Haapkylä, J., Seymour, A.S., Trebilco, J., \& Smith, D. (2007). Coral disease prevalence and coral health in the Wakatobi Marine Park, South-east Sulawesi, Indonesia. J. Mar. Biol. Ass. U.K., 87(5582), 1-12.
Harvell, D., Jordán-Dahlgren, E., Merkel, S., Rosenberg, E., Raymundo, L., Smith, G., Weil, E., \& Willis, B. (2007). Coral disease, environmental drivers, coral and microbial associates balance between and the by the coral disease working group of the global environmental facility coral reef targeted research program. Oceanography, 20(1), 172-195.

Hirayam, H., Takai, K., Inagaki, F., Nealson, K.H., \& Horikoshi, K. (2005). Thiobacter subterraneus gen. nov., sp. nov., an obligately chemolithoautotrophic, thermophilic, sulfuroxidizing bacterium from a subsurface hot aquifer. IJSEM, 55(1), 467-472.

Humason, G.L. (1962). Animal tissue techniques. W. H. Freeman and Co. San Francisco, $468 \mathrm{pp}$.

Johan, O., Bengen, D.G., Zamani, N.P., Suharsono, \& Sweet, M.J. (2013). The distribution and abundance of black band disease and white syndrome in Kepulauan Seribu, North of Jakarta, Indonesia. Disease of Aquatic Organism, 17 pp. (in progress).

Kiernan, J.A. (1990). Histological and histochemical methods. $2^{\text {nd }}$ Eds., Pergamon Press, New York.

Lee, K., \& Ruby, E.G. (1995). Symbiotic role of the viable but nonculturable state of Vibrio fischeri in Hawaiian Coastal Seawater. Appl. Environ. Microbiol., 61 (1), 278-283.

Lomans, B.P., Leijdekkers, P., Wesselink, J.J., Bakkes, P., Pol, A., Drift, C., \& Op den Camp, H.J.M. (2001). Obligate sulfide-dependent degradation of methoxylated aromatic compounds and formation of methanethiol and dimethyl sulfide by a freshwater sediment isolate, Parasporobacterium paucivorans gen. nov., sp. nov. Appl. Environ. Microbiol. September; 67(9), 4017-4023. doi:10.1128/AEM.67.9.4017-4023.2001.

Martinez-Canovas, M.J., Bejar, V., MartinezCheca, F., \& Quesada, E. (2004). Halomonas anticariensis sp. nov., from Fuente de Piedra, a saline-wetland wildfowl reserve in Ma' laga, Southern Spain. International Journal of Systematic and Evolutionary Microbiology, 54, 1329-1332.

Muyzer, G., de Waal, E.C., \& Uitterlinden, A.G. (1993). Profiling of complex microbial populations by denaturing gradient gel electrophoresis analysis of polymerase chain reaction-amplified genes encoding for $16 \mathrm{~S}$ rRNA. Appl. Environ. Microbiol., 59, 695-700.

Nakagawa, S., Shtaih, Z., Banta, A., Beveridge, 
T.J., Sako, Y., \& Reysenbach, A.L. (2005). Sulfurihydrogenibium yellowstonense sp. nov., an extremely thermophilic, facultatively heterotrophic, sulfur-oxidizing bacterium from Yellowstone National Park, and emended descriptions of the genus Sulfurihydrogenibium, Sulfurihydrogenibium subterraneum and Sulfurihydrogenibium azorense. International Journal of Systematic and Evolutionary Microbiology, 55, 2263-2268.

Ojima, T., Saburi, W., Yamamoto, T., \& Kudo, T. (2012). Characterization of Halomonas sp. H1 $1 \alpha$-glucosidase activated by monovalent cations and its application for efficient synthesis of $\alpha$-D-glucosylglycerol. Appl. Environ. Microbiol., 44 pp. doi:10.1128/ AEM.07514-11.

Raina, J.B., Tapiolas, D., Willis, B.L., \& Bourne, D.G. (2009). Coral-associated bacteria and their role in the biogeochemical cycling of sulfur. Applied and Environmental Microbiology, 75(11), 3492-3501.

Ramos-Flores, T. (1983). Lower marine fungus associated with black line disease in star corals (Montastraea annularis). Biol. Bull., 165, 429-435.

Ravindran, J., Raghukumar, C., \& Raghukumar, S. (1998). Disease and stress-induced mortality of corals in Indian reefs and observations on bleaching of corals in the Andamans.

Richardson, L.L., Miller, A.W., Broderick, E., Kaczmarsky, L., Gantar, M., Stani, D., \& Sekar, R. (2009). Sulfide, microcystin, and the etiology of black band disease. Diseases of aquatic organisms, 87(1-2), 79-90. doi:10.3354/dao02083

Richardson, L.L. (1996). Horizontal and vertical migration patterns of Phormidium corallyticum and Beggiatoa spp. associated with Black-Band Disease of corals. Microb. Ecol., 32,323-335.

Richardson, L.L. (1998). Coral disease: what is really known? Tree, 13(11), 438-443.

Richardson, L.L., Kuta, K.G., Schnell, S., \& Carlton, R.G. (1997). Ecology of the black band disease microbial consortium. Proc. $8^{\text {th }}$ Intl. Coral Reef Symp. 1, 597-600.

Richardson, L.L., Miller, A.W., Broderick, E., Kaczmarsky, L., Gantar, M., Stanic, D., \& Sekar, R. (2009). Dis. Aqual. Org., 87, 79-99.

Rohwer, F., Seguritan, V., Azam, F., \& Knowlton, N. (2002). Diversity and distribution of coral-associated bacteria. Mar. Ecol. Prog. Ser.,
243, 1-10.

Rosenberg, E., \& Ben-Haim, Y. (2002). Microbial diseases of corals and global warming. Environmental Microbiology, 4(6), 31 8-326.

Rosenberg, E., \& Loya, Y. (2004). Coral health and disease. Springer, Berlin.

Sabdono, A., \& Radjasa, O.K. (2006). Anti-bacterial property of a coral-associated bacterium Bacillus sp. against coral pathogenic BBD (Black Band Disease). Journal of Coastal Development, 9(3), 175-182.

Santos, P., Estrada-de los, Vinuesa, P., Hirsch, A.M., Martinez-Aguilar, L., \& CaballeroMellado, J. (2013). Phylogenetic analysis of burkholderia species by multilocus sequence analysis. Curr. Microbiol., 10 pp. doi: 10.1007/s00284-013-0330-9.

Sato, Y., Willis, B.L., \& Bourne, D.G. (2010). Successional changes in bacterial communities during the development of black band disease on the reef coral, Montipora hispida. The ISME Journal, 4(2), 203-214. doi: 10.1038/ismej.2009.103.

Sekar, R., Mills, D.K., Remily, E.R., Voss, J.D., \& Richardson, L.L. (2006). Microbial communities in the surface mucopolysaccharide layer and the black band microbial mat of black band-diseased Siderastrea siderea. Applied and Environmental Microbiology, 72(9), 5963-73. doi:10.1128/AEM.0084306.

Smith, D., Leary, P., Bendall, M., Flach, E., \&Jones, R. (2014). A novel investigation of a blisterlike syndrome in aquarium Echinopora lamellosa. PLoS ONE, 9(5), e97018. doi: 10.1371/j8.ournal.pone.009701

Small, A.L., \& McFall-Ngai, M.J. (1999). A halide peroxidase in tissues that interact with bacteria in the host squid Euprymna scolopes. J. Cellul. Biochem., 72, 445-457.

Sweet, M.J., Croquer, A., \& Bythell, J.C. (2011). Development of bacterial biofilms on artificial corals comparison to surface-associated microbes of hard corals. PLoS ONE, 6(6), 1-14.

Sweet, M.J., Jones, R., \& Bythell, J.C. (2012). Coral diseases in aquaria and in nature. Jurnal of the Marine Biological Association of the United Kingdom, 92(4), 791-801.

Sutherland, K.P., Porter, J.W., \& Torres, C. (2004). Disease and immunity in caribbean and Indo-Pacific zooxanthellate corals. Mar. Eco. Prog. Ser., 266, 273-302.

Venkateswaran, K., \& Dohmoto, N. (2000). Pseudoalteromonas peptidolytica sp. nov., 
a novel marine mussel-thread-degrading bacterium isolated from the Sea of Japan. International Journal of Systematic and Evolutionary Microbiology, 50, 565-574.

Viehman, S., Mills, D.K., Meichel, G.W., \& Richardson, L.L. (2006). Culture and identification of Desulfovibrio spp. from corals infected by black band disease on Dominican and Florida Keys reefs. Dis. Aquat. Org., 69, $119-127$.

Vynne, N.G. (2011). Bioactivity and phylogeny of the marine bacterial genus Pseudoalteromonas. Technical University of Denmark, National Food Institute, Division of Industrial Food Research. Ph.D. thesis.
Willis, B.L., Page, C.A., \& Dinsdale, E.A. (2004). Coral disease on the Great Barrier Reef. In Coral Health and Disease, Rosenberg, E., Loya, Y. (eds), Springer-Verlag, Berlin, p. 69104.

Yabuuchi, E., Yamamoto, H., Terakubo, S., Okamura, N., Naka, T., Fujiwara, N., Kobayashi, K., Kosakoand, Y., \& Hiraishi, A. (2001). Proposal of Sphingomonas wittichii sp. nov. for strain RW1T, known as a dibenzo-p-dioxin metabolizer. International Journal of Systematic and Evolutionary Microbiology, 51, 281-292. 